\title{
SAK ETAP, Kualitas Laporan Keuangan dan Jumlah Kredit yang diterima UMKM
}

\author{
A A Krisna Murti ${ }^{*}$, A A Ayu Erna Trisnadewi ${ }^{2}$, Luh Diah Citraresmi ${ }^{3}$, Komang Adi \\ Kurniawan Saputra 4
}

1,2,4 Universitas Warmadewa, Denpasar-Indonesia

3 Universitas Dhyana Pura, Denpasar-Indonesia

\author{
A R T I C L E I N F O \\ Article history: \\ Received 15 September \\ 2018 \\ Received in revised form \\ 22 September 2018 \\ Accepted 15 November \\ 2018 \\ Available online 12 \\ December 2018

\begin{tabular}{l}
\hline Kata Kunci: \\
Kualitas Laporan \\
Keuangan, SAK ETAP, dan \\
UMKM \\
Keywords: \\
Financial Reporting Quality, \\
SAK ETAP, and SMEs
\end{tabular} \\ Kata Kunci: \\ ETAP, dan \\ Financial Reporting Quality,
}

\begin{abstract}
A B S T R A K
Persiapan dan pemanfaatan laporan keuangan yang merupakan bagian dari aspek keuangan yang dapat membantu usaha kecil menengah (UKM) dalam mengembangkan bisnis. Informasi akuntansi yang terkandung dalam laporan keuangan dapat digunakan untuk pengambilan keputusan manajemen, mengurangi biaya agensi dan sebagai informasi untuk kreditur (Allee dan Yohn 2009; Cassar 2009). Pada bulan Mei 2009 Dewan Standar Akuntansi Keuangan telah mengeluarkan Standar Akuntansi Keuangan Entitas tanpa Akuntabilitas Publik (SAK ETAP), efektif pada tanggal 1 Januari 2011. Penelitian ini bertujuan untuk mengetahui hubungan antara kualitas laporan keuangan dan SAK ETAP terhadap jumlah kredit yang diterima oleh UKM. Penelitian ini merupakan penelitian kuantitatif, menggunakan data primer, pengumpulan data menggunakan kuesioner yang disebarkan kepada 100 responden online dan offline yang berlokasi di Jakarta, Jawa Barat dan Bali. Hasil penelitian ini menunjukkan bahwa kualitas laporan keuangan mempengaruhi jumlah kredit yang didapat oleh UMKM yang berarti bahwa semakin berkualitas laporan keuangan jumlah kredit yang dapat diperoleh lebih besar dari perusahaan yang tidak memiliki laporan keuangan yang kurang berkualitas. Penelitian ini membuktikan bahwa kualitas laporan keuangan SME menjadi pertimbangan pihak luar dalam mengambil keputusan,
\end{abstract} terbukti dengan pengaruh kualitas laporan keuangan pada jumlah kredit yang diterima oleh UKM. Informasi atau sosialisasi, latar belakang pendidikan memiliki pengaruh positif dan signifikan terhadap pemahaman pengusaha tentang SAK ETAP.

\section{A B S T R A C T}

Preparation and utilization of financial statements that are part of the financial aspects that can help small medium enterprise (SMEs) in developing the business. Accounting information contained in the financial statements can be used for management decision making, reducing agency costs and as information for creditors (Allee and Yohn 2009; Cassar 2009). In May 2009 the Financial Accounting Standards Board has issued the Financial Accounting Standards of Entities without Public Accountability (SAK ETAP), effective on January 1, 2011. This study aims to determine the relationship between the quality of financial statements and SAK ETAP on the amount of credit received by SMEs. This research is a quantitative research, using primary data, collecting data using questionnaires distributed to 100 respondents online and offline located in Jakarta, West Java and Bali. The results of this study show that the quality of financial statements affect the amount of credit obtained by SMEs which means that the more qualified financial statements the amount of credit that can be obtained greater than the companies that do not have the financial statements that are less qualified. This study proves that the quality of SME

\footnotetext{
* Corresponding author.

E-mail addresses: agungkrisnamurti@gmail.com (A A Krisna Murti)
} 
financial statements to be considered external parties in making decisions, as evidenced by the influence of the quality of financial statements on the amount of credit received by SMEs. Information or socialization, educational background has a positive and significant influence on the entrepreneur's understanding of SAK ETAP.

Copyright (C) Ekuitas: Jurnal Pendidikan Ekonomi. All rights reserved.

\section{Pendahuluan}

UMKM merupakan pilar penting dalam perekonomian Indonesia karena memiliki sebaran yang luas dengan jumlah yang banyak. Unit usaha yang banyak dan menyebar mendorong penyerapan tenaga kerja yang lebih banyak dibandingkan dengan sektor lain seperti yang telah disajikan pada tabel 1.

Tabel 1. Perkembangan Data UMKM dan Usaha Besar Tahun 2012-2013

\begin{tabular}{|c|c|c|c|c|c|c|c|c|}
\hline \multirow{2}{*}{ No } & \multirow{2}{*}{ INOEATOR } & \multirow{2}{*}{ SATuaN } & \multicolumn{2}{|c|}{ TAHUN $2012^{-7}$} & \multicolumn{2}{|c|}{ TAMUN $2013^{-7}$} & \multicolumn{2}{|c|}{$\begin{array}{l}\text { DERKENE BNCAN } \\
\text { TWHUN 2012,2013 }\end{array}$} \\
\hline & & & AUMLAH & $\begin{array}{c}\text { PANGSA } \\
\text { anI }\end{array}$ & лМман & $\begin{array}{l}\text { DANGSA } \\
\text { NaI }\end{array}$ & NMLAH & (8) \\
\hline$=$ & 要 & $=$ & $=$ & $\frac{6}{6}$ & $=$ & $\frac{1}{a}$ & e & aㅐ \\
\hline \multirow[t]{6}{*}{1} & 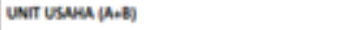 & (Unat) & 56.539560 & & $57.900 \mathrm{Jn}$ & & 1361.227 & 2,10 \\
\hline & 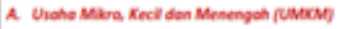 & (White) & 56.534 .592 & 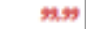 & 57.053.72 & 92. & 1.561 .129 & 241 \\
\hline & - Uhoto Maro (UM) & (Uine) & 55.956 .13 & sen & 57.180 .203 & $\operatorname{sen}$ & 1331237 & 2.00 \\
\hline & - Uhate Kedi (UX) & (Unet) & 629.418 & 2.11 & 65422 & 1.13 & 24.803 & 3,94 \\
\hline & - Uhato Nenmpoh(UM) & (Unot) & 48937 & 0.09 & 52.106 & 0,09 & 3.130 & 6.35 \\
\hline & R. Unato Reserer (U6) & (Whit) & 4.968 & a.at & 5.065 & a.es & $\mathbf{s}$ & 199 \\
\hline \multirow[t]{6}{*}{2} & FERAGA KERLA (A+8) & (Orang) & 110.968 .154 & & 117.681 .244 & & $\cos 2000$ & 6.20 \\
\hline & 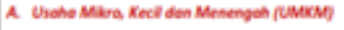 & (Proment & 107.657 .509 & 97,16 & 124.144 .062 & 9698 & 6.405 .53 & 6.03 \\
\hline & - Unoto Maro (UMe) & Prangy) & sossass & so.12 & 204.624 .46 & $\sec$ & LNGSA3 & $4 \pi$ \\
\hline & - Uhate Kedi (UK) & (Orangy) & 4535920 & 400 & 5.500 .231 & 43 & 2034262 & 22.80 \\
\hline & - Uhoto Menmpenalug & (Orongl) & 3.262 .023 & 294 & 3.969 .395 & 3.36 & 687363 & 21,07 \\
\hline & 2. Unato Rever (US) & (Onens) & 2.150 .65 & 204 & 250162 & 208 & 206sin & 2227 \\
\hline \multirow[t]{6}{*}{3} & 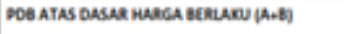 & (Aa. Milvar) & $8.241 .84,3$ & & 9.014951 .2 & & moscs & 9.38 \\
\hline & 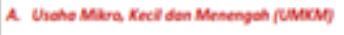 & (tha Meiven) & $4.869 .568,1$ & 5908 & $5.440 .007,9$ & 60.34 & 502.439 .8 & $11, n$ \\
\hline & - Uroho Maro (UMe) & (Ra Meinal) & 2951.220 .6 & 35.81 & 2.325564 & 36.90 & $3 \pi .4462$ & $12 \pi$ \\
\hline & - Uhato Kecil (US) & (6). Mipar) & $7 x+122,2$ & 208 & 876.385.3 & $2, n$ & nexa, & 2.81 \\
\hline & - Uhoto NenmpencuMg & (the Minan & 1.120 .325 .3 & 21.59 & 2237057,8 & $13, n$ & 216.732 .5 & 10,42 \\
\hline & R. Unato Reser (Cb) & (kno. Minar) & $332 \times 6.1$ & $\operatorname{sans}$ & 2.5749823 & 32.66 & 2002602 & 6.01 \\
\hline \multirow[t]{6}{*}{4} & DOB ATAS DASAR HaAGA KONSTAN 2000 (A.6) & (Ro. Miver) & $2525.120,4$ & & 2690.3148 & & 145.1944 & $5, \pi$ \\
\hline & 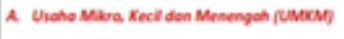 & (the. Minow) & 2.451 .460 .2 & 57,48 & $1.536928 \pi$ & 57.56 & As.4ses & $\sin$ \\
\hline & - Unoho Mars (UMe) & (Na Melor) & 790.205 .6 & $32 x$ & 2007.804 .50 & 30.25 & 26.9789 & 2.15 \\
\hline & - Unate Kenil (UR) & (6) Mipar) & 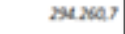 & 12.65 & $30.25 \times 19$ & 12.83 & 483.35 & 16,42 \\
\hline & - Uhato Menmogh(UM) & (the Mipar) & $36.3 n s$ & 2est & $3 a 6 \operatorname{sas} 00$ & $10.0 s$ & 20.261 .1 & 5.50 \\
\hline & R. Unato Rerier (U9) & (Fan Manes) & 107.660 .1 & e.52 & $2.233 .396,05$ & 42,44 & $\operatorname{sen} 9$ & 5,36 \\
\hline
\end{tabular}

Sumber: Kementrian Koperasi dan Usaha Kecil

Kinerja sektor UMKM dipengaruhi oleh faktor eksternal dan internal. Faktor internal merupakan faktor yang bersumber dari dalam usaha itu sendiri meliputi sumber daya manusia baik pemilik usaha, tim manajemen tertinggi hingga staf; aspek finansial, aspek teknis produksi; dan aspek pemasaran. Sedangkan faktor eksternal merupakan faktor yang berasal dari luar usaha tapi memiliki pengaruh terhadap keberlangsungan usaha. Faktor eksternal terdiri dari kebijakan pemerintah terutama kebijakan ekonomi, aspek sosial budaya dan juga ekonomi, serta peranan lembaga terkait seperti perguruan tinggi, lembaga non profit, dan juga lembaga pemerintahan (Mc Commick et.al,1997; Zang, 2001; Lesceviva, 2004; Maupa, 2004). Keunggulan kompetitif wajib dimiliki oleh UMKM agar produk atau programprogram yang dihasilkan mampu bersaing di pasar lokal maupun global. Untuk mencapai keunggulan kompetitif, salah satu faktor kunci yang mempengaruhi adalah informasi keuangan yang baik. Penyusunan dan pemanfaatan laporan keuangan yang merupakan bagian dari aspek keuangan yang dapat membantu UMKM dalam mengembangkan usaha. Informasi akuntansi yang terdapat pada laporan keuangan dapat digunankan untuk pengambilan keputusan management, mengurangi agency cost serta sebagai informasi untuk kreditur (Allee and Yohn 2009; Cassar 2009). Penelitian yang dilakukan Cassar (2009) menemukan bahwa usaha kecil yang memiliki laporan keuangan berkualitas dan diaudit lebih meyakinkan kreditor dalam memberikan kredit.

Kemudahan tersebut tidak serta merta mendorong para pelaku usaha melakukan pembukuan dan pelaporan dengan baik. UMKM masih mengalami permasalahan dalam hal perencanaan, pencatatan dan pelaporan. Bank Indonesia (2011) menyatakan bahwa UMKM tidak memiliki informasi keuangan yang transparan dan terorganisir yang menyebabkan pemberi kredit memiliki kesulitan dalam memperoleh 
informasi mengenai kondisi keuangan dan usaha dari UMKM. Hal tersebut dapat menyebabkan bank kesulitan dalam meminimalisir risiko default atas kredit yang dapat disalurkan kepada UMKM. Kualitas laporan keuangan yang masih rendah dan praktek pembukuan UMKM tidak sesuai dengan standar akuntansi yang berlaku sehingga informasi yang dihasilkan tidak akurat sehingga tidak dapat mempengaruhi jumlah kredit yang diperoleh UMKM (Rudiantoro dan Siregar 2012; Sari 2012).

Pada bulan Mei 2009 Dewan Standar Akuntansi Keuangan (DSAK) telah mengeluarkan SAK ETAP (Standar Akuntansi Keuangan Entitas tanpa Akuntabilitas Publik), SAK ETAP efektif berlaku pada 1 Januari 2011. SAK ETAP berlaku untuk perusahaan yang tidak memiliki akuntabilitas publik signifikan dan menerbitkan laporan keuangan untuk tujuan umum (general purpose financial statement) bagi pengguna eksternal. SAK ETAP merupakan alternatif yang dikeluarkan oleh DSAK sebagai alternatif bagi UMKM termasuk di dalamnya sebagai pedoman dalam penyusunan laporan keuangan. Kelebihan SAK ETAP untuk UMKM yaitu lebih sederhana dibandingkan PSAK umum. Dengan berlakunya SAK ETAP harapannya adalah para pelaku UMKM dapat lebih mudah membuat laporan keuangan yang berguna untuk kemajuan bisnis perusahaan. Narsa et al (2012) menemukan beberapa kendala yang diahadapi UMKM dalam menerapkan SAK ETAP diantaranya tidak memiliki catatan transaksi yang baik dan tertib dan tidak memahami bentuk catatan transaksi keuangan.

Terdapat beberapa penelitian sebelumnya yang sudah membahas mengenai pengaruh kualitas laporan keuangan terhadap jumlah kredit yang diperoleh UMKM seperti yang dilakukan Cassar (2009) dan Rudiantoro dan Siregar (2012). Untuk penelitian mengenai SAK ETAP, penelitian yang telah dilakukan mencakup prospek penerapan (Rudiantoro dan Siregar, 2012), kemudian mengenai hambatan-hambatan yang dihadapi UMKM dalam menerapkan serta beberapa studi kasus yang meniliti mengenai penerapan SAK ETAP. Penelitian terdahulu belum ada yang meniliti menenai pengaruh penerapan SAK ETAP terhadap jumlah kredit yang diperoleh UMKM. Sehingga, penelitian ini ingin menutup GAP penelitian sebelumnya dengan menguji pengaruh kualitas laporan keuangan dan penerapan SAK ETAP terhadap perolehan kredit UMKM. Selain itu peneliti menguji faktor-faktor yang mempengaruhi pemahaman UMKM terhadap SAK ETAP.

\section{Kerangka Teoritis Dan Pengembangan Hipotesis}

Theory of Planned Behavior didasarkan pada asumsi bahwa manusia adalah makhluk yang rasional dan menggunakan informasi-informasi yang mungkin baginya secara sistematis. Orang memikirkan implikasi dari tindakan mereka sebelum memutuskan untuk melakukan atau tidak melakukan perilakuperilaku tertentu. Berdasarkan teori tersebut, penentu terpenting perilaku seseorang adalah intensi untuk berprilaku. Intensi individu untuk menampilkan suatu perilaku adalah kombinasi dari sikap untuk menampilkan perilaku tersebut dan norma subjektif. Sikap individu terhadap perilaku meliputi kepercayaan mengenai suatu perilaku, evaluasi terhadap hasil perilaku, norma subjektif, kepercayaankepercayaan normatif dan motivasi untuk patuh. Secara lebih lengkap Ajzen (2005) menambahkan faktor latar belakang individu ke dalam

Theory of planned behavior meyakini bahwa faktor latar belakang terdiri dari usia, jenis kelamin, suku, status sosial ekonomi, suasana hati, sifat kepribadian, dan pengetahuan mempengaruhi sikap dan perilaku individu terhadap sesuatu hal. Perbedaan lingkungan sosial mempengaruhi perbedaan informasi yang diperoleh seseorang tentang berbagai isu, informasi tersebut menjadi dasar kepercayaan atas dampak sebuah perilaku, ekspektasi normatif atas penting atau tidaknya sesuatu, dan tentang permasalahan yang akan dihadapi saat melalukan suatu perilaku. Dalam kategori ini Ajzen (2005), memasukkan tiga faktor latar belakang, yakni personal, sosial, dan informasi. Faktor personal adalah sikap umum seseorang terhadap sesuatu, sifat kepribadian (personality traits), nilai hidup (values), emosi, dan kecerdasan yang dimilikinya. Faktor sosial antara lain adalah usia, jenis kelamin (gender), etnis, pendidikan, penghasilan, dan agama. Faktor informasi adalah pengalaman, pengetahuan, dan ekspose pada media.

Latar belakang pendidikan menjadi faktor yang melatarbelakangi seseorang dalam mengambil keputusan, termasuk keputusan akuntansi. Solovida (2003) menyebutkan jenjang pendidikan menentukan tinggi rendahnya persiapan dan penggunaan informasi akuntansi. Rudiantoro dan Siregar (2012) menemukan bahwa jenjang pendidikan mempengaruhi pemahaman pengusaha terhadap SAK ETAP. Jenjang pendidikan yang tinggi dengan latar belakang akuntansi akan memudahkan karyawan bagian akuntansi dalam melaksanakan tugasnya. Staf akuntansi yang memiliki latar belakang pendidikan akuntansi akan menunjukan performa lebih baik dalam menjalankan tugasnya (Meuthia dan Endrawati, 2008).

Badan Pusat Statistik (BPS) mengklasifikasikan usaha berdasarkan jumlah tenaga kerjanya yang menyatakan bahwa jika suatu usaha memiliki 0 hingga 4 orang tenaga kerja maka usaha tersebut 
dinamakan usaha rumah tangga. Jika jumlah tenaga kerjanya 5 hingga 19 orang maka disebut usaha kecil, 20 hingga 99 orang disebut usaha menengah dan lebih dari 99 orang disebut usaha besar.

Tabel 2. Klasifikasi Usaha Menurut Jumlah Tenaga Kerja

\begin{tabular}{ccc}
\hline No & Kategori & Jumlah Tenaga Kerja \\
\hline 1 & Usaha Rumah Tangga & $0-4$ orang \\
2 & Usaha Kecil & $5-19$ orang \\
3 & Usaha Menengah & $20-99$ orang \\
4 & Usaha Besar & $\geq 99$ orang
\end{tabular}

Sumber: Badan Pusat

Tujuan akuntansi dan laporan keuangan pada dasarnya untuk menyediakan informasi keuangan suatu badan usaha yang akan digunakan oleh berbagai pihak yang berkepentingan sebagai dasar pengambilan suatu keputusan ekonomi. Untuk itu dibutuhkan suatu Standar Akuntansi Keuangan yang baik dan dapat dimengerti oleh berbagai pihak pengguna laporan keuangan. SAK yang berkualitas merupakan salah satu pedoman pokok untuk menyusun dan menyajikan laporan keuangan bagi perusahaan. Dengan adanya standar akuntansi yang baik, maka laporan keuangan dapat menjadi lebih berguna dan menciptakan transparansi bagi perusahaan (Prasetya, 2012). Oleh karena itu, mekanisme penyusunan standar akuntansi harus diatur sehingga dapat memberikan kepuasan kepada semua pihak yang berkepentingan (Fitakhurrokhmah, 2013). Indonesia memiliki standar akuntansi disusun dan disahkan oleh Dewan Standar Akuntansi Keuangan (DSAK). Adapun Tiga Pilar Standar Akuntansi Indonesia adalah standar Akuntansi Keuangan, standar Akuntansi Entitas tanpa Akuntabilitas Publik (ETAP), dan standar Akuntansi Syariah.

SAK ETAP adalah Standar Akuntansi Keuangan Entitas tanpa Akuntabilitas Publik yang telah disahkan oleh Dewan Standar Akuntansi Keuangan pada tanggal 19 Mei 2009. SAK ETAP diterapkan untuk penyusunan laporan keuangan yang dimulai pada atau setelah 1 Januari 2011. Sesuai dengan ruang lingkup SAK ETAP maka standar ini dimaksudkan untuk digunakan oleh entitas tanpa akuntabilitas publik. Entitas tanpa akuntabilitas publik yang dimaksud adalah entitas yang tidak memiliki akuntabilitas publik signifikan; dan tidak menerbitkan laporan keuangan untuk tujuan umum (general purpose financial statement) bagi pengguna eksternal. Contoh pengguna eksternal dalam kriteria kedua ini adalah: pemilik yang tidak terlibat langsung dalam pengelolaan usaha, kreditur dan lembaga pemeringkat kredit. Kriteria ETAP di atas bisa dibedakan dengan entitas yang memiliki akuntabilitas publik, yaitu jika: 1. Entitas telah mengajukan pernyataan pendaftaran atau entitas dalam proses pengajuan pernyataan pendaftaran pada otoritas pasar modal (BAPEPAM-LK) atau regulator lain untuk tujuan penerbitan efek di pasar modal, 2. Entitas menguasai aset dalam kapasitas sebagai fidusia untuk sekelompok besar masyarakat, seperti bank, entitas asuransi, pialang atau pedagang efek, dana pensiun, reksa dana, dan bank investasi, 3. Entitas yang memiliki akuntabilitas publik signifkan dapat menggunakan SAK ETAP jika otoritas berwenang membuat regulasi yang mengizinkan penggunaan SAK ETAP. Pada umumnya, entitas tanpa akuntabilitas publik adalah UMKM, oleh karena itu pengguna SAK ETAP akan banyak terdiri dari entitas dengan kategori UMKM.

Penelitian sebelumnya menunjukan banyak UMKM kurang memahami SAK ETAP, UMKM masih enggan membuat laporan keuangan dengan baik karena masih menganggap laporan kurang penting dan kurangnya pemahaman pengusaha UMKM mengenai bidang akuntansi(Ngadiman, 2014; Rudiantoro \& Siregar, 2012). Terdapat faktor-faktor yang dapat mempengaruhi pemahaman pengusaha terhadap standar keuangan, seperti karakteristik perusahaan dan karakteristik pengusaha. Pengusaha atau pemilik memilik peran besar dalam pengambilan keputusan UMKM, hal ini disebabkan pada kebanyakan UMKM masih dikelola langsung oleh pemilik modal. Ajzen (2005) melalui theory planned behavior meyakini bahwa faktor personal akan mempengaruhi seseorang dalam melakukan tindakan atau mengambil keputusan, yang termasuk faktor personal meliputi jenjang pendidikan, latar belakang pendidikan, dan jenis kelamin. Penelitian sebelumnya menunjukan bahwa pemberian informasi atau sosialisasi, Ukuran usaha serta tingkat pendidikan pendidikan pemilik Faktor yang mempengaruhi pemahaman UMKM terhadap standar akuntansi (Rudiantoro \& Siregar 2012; Holmes dan Niccole1989 ; Gray 2006; Arismawati, Sulindawati, \& Atmadja 2017). Semakin besar suatu usaha maka akan lebih mudah merekrut sumber daya handal dan memiliki kompetensi sehingga mempermudah dalam hal pemahaman teradap 
sebuah standar baru termasuk SAK ETAP. Jenjang pendidikan dan Latar belakang pendidikan pemilik akan memudahkan dalam pemahaman dan penerapan informasi baru termasuk dalam pemahaman serta implementasi SAK ETAP. Sehingga dapat ditarik hipoteisis sebagai berikut :

H1a : Ukuran Usaha memiliki pengaruh positif terhadap pemahaman pengusaha UMKM mengenai SAK ETAP.

H1b : Jenjang pendidikan memiliki pengaruh positif terhadap pemahaman pengusaha UMKM mengenai SAK ETAP.

H1c : Latar belakang pendidikan meningkatkan pengaruh jenjang pendidikan terhadap pemahaman pengusaha UMKM mengenai SAK ETAP.

H1d : Informasi memiliki pengaruh memiliki pengaruh positif terhadap pemahaman pengusaha UMKM mengenai SAK ETAP.

Laporan keuangan perusahaan menjadi dasar informasi dalam pengambilan keputusan. informasi akuntansi dihasailkan dapat digunakan alat kontrol management, mengurangi agency cost dan dapat digunakan pihak ekternal dalam menilai kinerja perusahaan seperti pidak bank yang akan memberikan kredit terhadap perusahaan. (Allee \& Yohn, 2009; Cassar, 2009; Chen, Hope, Li, \& Wang, 2011). Baas dan Schrooten (2006) menyatakan bahwa laporan keuangan menjadi acuan perbankan untuk melihat apakah suatu perusahaan memiliki kemampuan dalam mengembalikan kredit yang dipinjam. UMKM mendapat banyak hambatan dan memiliki akses terbatas terhadap pembiayaan jika dibandingkan denga perusahaan besar, salah satu penyebabnya adalah kurang berkualitasnya laporan keungan dan keengganan UMKM dalam membuat laporan keuangan (Beck dan Demirguc-Kunt 2006; Bank Indonesia 2011; Rudiantoro dan Siregar 2012; Sari, 2013; Ngadiman 2014). Diterbitkannya SAK ETAP yang lebih sederhana dibandingkan standar akuntansi keuangan, diharapkan dapat mempermudah perusahaan dalam menyusun laporan keuangan agar lebih handal, transparan dan dapat dibandingkan. Dengan penerepan standar keuangan UMKM dapat meningkatkan kualitas informasi akuntansi yang dihasilkan oleh perusahaan (Olango 2014; Prasetya 2012 ).

Selain kualitas laporan keuangan Baas dan Schrooten (2006) menyebutkan bahwa Asset Based Lending atau jaminan berupa asset menjadi salah satu faktor yang dipertimbangkan oleh bank dalam memberikan kredit. Ukuran usaha dan lama usaha berdiri juga menjadi faktor dalam pemberian kredit, semakin besar dan lama suatu usaha bisa menjadi signal positif bagi pemberi kredit (Rudiantoro \& Siregar, 2012). Dari uraian diatas dapat ditarik hipotesis :

UMKM

H2a : Kualitas laporan keuangan berpengaruh positif terhadap jumlah kredit yang diterima

H2b : Penerapan SAK ETAP berpengaruh positif terhadap jumlah kredit yang diperoleh UMKM

H2c : : Ukuran Usaha berpengaruh positif terhadap jumlah kredit yang diterima UMKM.

H2d : Lama Usaha berpengaruh positif terhadap jumlah kredit yang diterima UMKM.

H2e : Jumlah Jaminan berpengaruh positif terhadap jumlah kredit yang diterima UMKM.

\section{Metode}

Penelitian ini menggunakan metode kuantitatif, pengumpulan data menggunakan kuisoner yang disebar kepada 100 responden secara online dan offline yang berlokasi di Jakrarta, Jawa Barat dan Bali. Model penelitian menguji hipotesis yang telah dikembangkan sebelumnya dengan menggunakan regresi berganda. Pada penelitian ini menggunakan 3 model masing-masing untuk menguji H1, H2 dan H3. Adapun model penelitiannya adalah sebagai berikut :

PNJMNi $=\alpha 1+\alpha 2$ LAPKEUi+ $\alpha 3$ ETAPi $+\alpha$ 4UKURANi $+\alpha 5$ UMURi+ $\alpha 6$ JAMINAN +

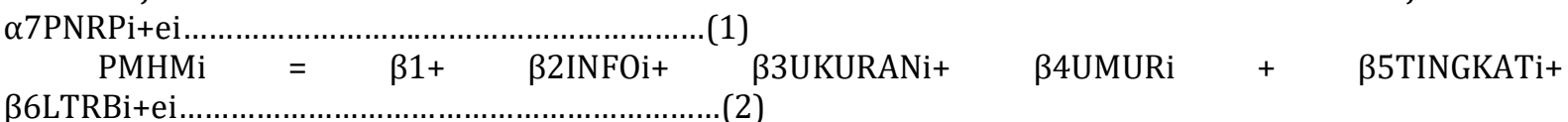

Definisi dan Pengukuran Variabel Penelitian, pada bagian ini akan dijelaskan mengenai defisini setiap variabel yang digunakan dalam penelitian ini baik variabel dependen ataupun independen. Pengukuran variabel pada penelitian ini mengacu pada penelitian yang yang dilakukan oleh Rudiantoro dan Siregar (2012) dengan melakukan perubahan dibeberapa bagian.

Jumlah pinjaman yang diterima UMKM

Diukur dari jumlah pinjaman yang diterima UMKM, peneliti memberikan poin untuk jumlah kredit yang di terima, poin yang diberkan atas jawaban dari pertanyaan ini adalah 1 untuk kredit kurang dari Rp10.000.000, 2 untuk (Rp10.000.001 - Rp25.000.000), 3 untuk Rp25.000.001 - Rp50.000.000, 4 untuk Rp50.000.001 - Rp100.000.000, serta 5 untuk kredit lebih dari Rp100.000.000. 
Penerapan SAK ETAP Diukur menggunakan variabel dummy, dimana jika perusahaan telah menggunakan SAK ETAP diberikan skor 1 dan skor 0 untuk yang lainnya.

Kualitas laporan keuangan dinilai menggunakan menggunakan indeks, dimana indeks kualitas laporan keuangan dinilai berdasarkan: (1) Pelaku UMKM melakukan pembukuan akuntansi atau tidak, jika menjawab "Ya" maka mendapat poin 1, dan 0 untuk jawaban "Tidak"; (2) Terdapatnya bagian atau divisi atau pegawai khusus dalam perusahaan yang bertanggung jawab terkait pembukuan dan pelaporan keuangannya, poin 1 diberikan jika menjawab "Ada" dan 0 untuk jawaban "Tidak"; (3) Terdapatnya software akuntansi yang mendukung pembukuannya, poin 1 diberikan jika menjawab "Ya" dan 0 untuk jawaban "Tidak". (4) Awal laporan keuangan pertama kali dibuat. Nilai diberikan sesuai dengan jumlah tahun dari awal laporan keuangan dibuat hingga tahun 2016; (5) Rutin atau tidaknya pembukuan transaksi serta pelaporan keuangan dibuat, jika menjawab "Rutin" mendapat poin 1 dan 0 untuk jawaban "Tidak"; (6) Standar akuntansi yang digunakan, jika menjawab pilihan jawaban "PSAK", atau "Aturan Perpajakan" atau "Lainnya" mendapat poin 1, dan poin 0 untuk jawaban "Tidak Tahu"; (7) Komponen laporan keuangan yang akan dibuat (terdapat 5 komponen laporan keuangan). Dapat menjawab lebih dari 1 pilihan dan masing-masing pilihan memiliki poin 1, dengan poin maksimal adalah 5 . Poin yang didapat dari masing-masing pertanyaan tersebut dijumlahkan sehingga mendapat angka indeks kualitas laporan keuangan.

Ukuran usaha ditentukan berdasarkan jumlah karyawan, total aset, dan nilai penjualan dengan memberikan skoring sesuai jawaban dan kemudian dijumlahkan. Jumlah asset dan penjualan menggunakan interval untuk menjaga kerahasiaan data responden.

Tingkat Pendidikan merupakan pendidikan terakhir yang ditempuh pemilik atau manager keuangan UMKM. Pengukuran untuk variabel ini adalah 1 jika pendidikan dibawah SMA/SMK, 2 jika mempunyai pendidikan SMA/SMK, 3 jika S1, 4 untuk jenjang pendidikan S2, serta 5 jika berpendidikan S3.

Jika mempunyai latar belakang pendidikan Akuntansi diberi nilai 3, sedangkan jika berlatar belakang pendidikan Manajemen dan Ekonomi diberi nilai 2, serta untuk latar belakang pendidikan lainnya (termasuk jika berlatar belakang pendidikan SMA) mendapat nilai 1.

Lama berdirinya usaha atau umur usaha diukur dengan pemberia skor, Nilai 1 diberikan jika lama usaha adalah 1 tahun, kemudian 2 untuk lama usaha berdiri sejak 2 tahun, 3 untuk lama usaha berdiri dari 3, 4 untuk lama usaha berdiri 4 tahun, 5 untuk usaha yang berdiri 5 tahun dan 6 diberikan untuk usaha yang berdiri diatas 6 tahun.

Jumlah jaminan merupakan besarnya jaminan yang diberikan pengusaha UMKM saat meminjam kredit di bank. Jumlah jaminan dinilai dengan pemberian poin pada jawaban yang dipilih. Poin yang diberikan untuk jawaban atas pertanyaan ini adalah 1 bila tidak ada jaminan, 2 untuk jaminan kurang dari Rp10.000.000, 3 untuk Rp10.000.001- Rp25.000.000, 4 untuk Rp50.000.001- Rp.100.000.001, dan 5 untuk lebih dari Rp100.000.000.

Populasi adalah wilayah generalisasi yang terdiri dari obyek atau subyek yang mempunyai kausalitas dan karakteristik tertentu yang ditetapkan oleh peneliti untuk dipelajari dan kemudian ditarik kesimpulannya (Sugiyono, 2008). Populasi dalan penelitian ini adalah seluruh pelaku UMKM yang berada di pulau Jawa dan Bali. Pulau Jawa dipilih karena jumlah UMKM di Indonesia paling banyak terdapat di pulau Jawa, sedangkan Bali adalah daerah yang minim sumber daya alam sehingga perekonmian bergantung pada pariwisata dan UMKM. Pengambilan sampel dilakukan dengan menggunakan simple random sampling, degan kriteria termasuk UMKM dari segi omset dan total asset, untuk sebagian sampel adalah perusahaan yang sudah menerapkan SAK ETAP.

Tabel 3. Descriptive Statistics

\begin{tabular}{llllll}
\hline Variable & Obs & Mean & Std. Dev. & Min & Max \\
\hline CREDIT & 51 & 2.156863 & 1.376554 & 0 & 4 \\
FRQ & 51 & 11.15686 & 2.887023 & 7 & 16 \\
FRQXIMPLEMENTATION & 51 & 0.176471 & 0.385013 & 0 & 1 \\
SIZE & 51 & 5.45098 & 2.955089 & 3 & 12 \\
COLLATERAL & 43 & 2.488372 & 1.162348 & 0 & 4 \\
UNDERSTANDING & 51 & 1.352941 & 0.559412 & 1 & 3 \\
LEVEL & 51 & 2.764706 & 1.011696 & 1 & 4 \\
BACKGROUND & 51 & 1.921569 & 0.844823 & 1 & 3 \\
INFO & 51 & 0.294118 & 0.460179 & 0 & 1 \\
AGE & 51 & 2.078431 & 1.036207 & 1 & 4 \\
\hline
\end{tabular}


Dari 100 kusioner yang dikirimkan 82 yang kembali, 31 kuisioner tidak lengkap terutama pada jumlah omset dan aset. Sehingga sampel yang kami gunakan adalah 51 perusahaan. Persebaran sampel berdasarkan lokasi usaha adalah Bali 42 perusahaan, Depok 3 perusahaan dan 6 perusahaan lagi berada di Jakarta. Tingkat pendidikan responden sebagian besar adalah S1 (51\%), disusul S2 (21\%), SMA (20\%) dan Diploma (6\%). Tabel 3 menyajikan statistik deskriptif dari sampel yang diperoleh, rata-rata skor untuk kualitas laporan keuangan adalah 11,15 termasuk dalam kategori sedang. Variabel ukuran usaha menunjukan range yang cukup jauh, dengan nilai paling kecil 3 yang tergolong pada usaha mikro dan tertinggi 12 yang tergolong pada usaha menengah.

\section{Hasil dan pembahasan}

Tabel 4. Perbandingan ukuran usaha kualitas laporan keuangan dan penerapan SAK ETAP

\begin{tabular}{|c|c|c|c|c|}
\hline \multirow{2}{*}{ Ukuran usaha } & \multicolumn{3}{|c|}{ Kualitas Laporan Keuangan } & \multirow{2}{*}{$\begin{array}{c}\text { Penerapan SAK } \\
\text { ETAP }\end{array}$} \\
\hline & Bagus & Sedang & Buruk & \\
\hline Menengah & 7 & 3 & 1 & 7 \\
\hline Kecil & 4 & 6 & 2 & 4 \\
\hline Mikro & 3 & 7 & 18 & 3 \\
\hline
\end{tabular}

Pada tabel 4 dapat dilihat bahwa sebagian besar kualitas laporan keuangan masih buruk terutama pada kelompok usaha mikro, untuk usaha kecil kualitas laporan keuangan masih variatif dan sebagian besar masuk pada kategori sedang, ada dua perusahaan kecil yang sudah menerapkan SAK ETAP. Untuk kelompok usaha menengah sebagaian besar memiliki kualitas laporan keuangan yang bagus, ada 7 dari 10 perusahaan yang sudah menerapkan SAK ETAP.

Tabel 5 menunjukan jumlah kredit yang diterima oleh responden, dimana pada penelitian jumlah kredit yang diterima cukup bervariasi, sebagian besar jumlah kredit yang diterima adalah 50-100 juta (17 perusahaan), disusul 5-25 juta (11 perusahaan), diatas 500 juta ( 9 perusahaan), 25-50 juta (6 perusahaan), sedangkan perusahaan yang tidak memiliki kredit sebanyak 8 perusahaan yang berasal dari kelompok usaha mikro. Jika dikaitkan dengan kualitas laporan keuangan, dari 9 perusahaan penerima kredit diatas 500 juta, 7 perusahaan memiliki kualitas laporan keuangan yang bagus dan menerapkan SAK ETAP, 2 lainnya sedang serta tidak menerapkan, sebagian besar jumlah kredit diatas 500 juta diperoleh oleh perusahaan dengan ukuran usaha menengah. Perusahaan yang mendapatkan kredit 5-25juta dan perusahaan yang tidak memiliki kredit, kualitas laporan keuangan cenderung buruk dan tidak menerapkan SAK ETAP, jika dilihat dari ukuran usahanya sebagian besar berasal dari kelompok usaha mikro.

Hasil penelitian menyajikan bahwa kualitas laporan keuangan berpengaruh terhadap jumlah kredit yang diperoleh UMKM yang berarti bahwa semakin berkualitas laporan keuangan jumlah kredit yang dapat diperoleh semakin besar dibandingkan dengan perusahaan yang tidak memiliki laporan keuangan yang kurang berkualitas. Hasil ini berbeda dengan penelitian sebelumnya (Rudiantoro \& Siregar, 2012) yang menunjukan kualitas laporan keuangan tidak berpengaruh signifikan terhadap jumlah kredit yang diperoleh UMKM. Hasil ini mengkonfirmasi signaling theory menunjukan bahwa laporan keuangan digunakan oleh pihak ekternal sebagai dasar pengambilan keputusan.

Tabel 5. Hasil Regresi

\begin{tabular}{|c|c|c|c|c|}
\hline \multirow[t]{2}{*}{ Variables } & \multicolumn{2}{|c|}{$\begin{array}{l}\text { Model } 1 \\
\text { CREDIT }\end{array}$} & \multicolumn{2}{|c|}{$\begin{array}{c}\text { Model } 2 \\
\text { UNDERSTANDING } \\
\end{array}$} \\
\hline & $\begin{array}{l}\text { Coefficient } \\
\text { (Std. Err.) }\end{array}$ & $\begin{array}{l}\text { t-Statistic } \\
(P>|t|)\end{array}$ & $\begin{array}{l}\text { Coefficient } \\
\text { (Std. Err.) }\end{array}$ & $\begin{array}{l}\text { t-Statistic } \\
(P>|t|)\end{array}$ \\
\hline FRQ & $\begin{array}{l}0.0664 \\
(0.037)\end{array}$ & $\begin{array}{l}1.76^{*} \\
(0.086)\end{array}$ & & \\
\hline FRQXIMPLE & $\begin{array}{l}0.012 \\
(0.009)\end{array}$ & $\begin{array}{l}1.25 \\
(0.218)\end{array}$ & & \\
\hline SIZE & $\begin{array}{l}0.041 \\
(0.022)\end{array}$ & $\begin{array}{l}1.9^{*} \\
(0.066)\end{array}$ & $\begin{array}{l}0.015 \\
(0.0179)\end{array}$ & $\begin{array}{l}0.84 \\
(0.407)\end{array}$ \\
\hline COLLATERAL & $\begin{array}{l}0.709 \\
(0.139)\end{array}$ & $\begin{array}{l}5.07 * * * \\
(0.000)\end{array}$ & & \\
\hline AGE & $\begin{array}{l}-0.030 \\
(0.0337)\end{array}$ & $\begin{array}{l}-0.87 \\
(0.389)\end{array}$ & $\begin{array}{l}-0.12 \\
(0.068)\end{array}$ & $\begin{array}{l}-1.76^{*} \\
(0.085)\end{array}$ \\
\hline LEVEL & & & $\begin{array}{l}-0.0329 \\
(0.0498)\end{array}$ & $\begin{array}{l}-0.66 \\
(0.513)\end{array}$ \\
\hline BACKGROUND & & & $\begin{array}{l}0.234 \\
(0.109)\end{array}$ & $\begin{array}{l}2.15 * * \\
(0.037)\end{array}$ \\
\hline INFO & & & $\begin{array}{l}0.63 \\
(0.209)\end{array}$ & $\begin{array}{l}3.01 * * * \\
(0.004)\end{array}$ \\
\hline Constant & -0.208 & & $0.976 * * *$ & \\
\hline & $(0.207)$ & & $(0.165)$ & \\
\hline Observations & 43 & & 51 & \\
\hline R-squared & 0.948 & & 0.652 & \\
\hline
\end{tabular}


Penelitian ini membuktikan bahwa kualitas laporan keuangan UKM menjadi bahan pertimbangan pihak eksternal dalam mengambil keputusan, terbukti dari pengaruh kualitas laporan keuangan terhadap besaran kredit yang diterima UKM. Ukuran usaha dan anggunan terbukti memiliki hubungan positif dan signifikan terhadap jumlah kredit yang diterima UKM. Sedangkan penerapan SAK ETAP tidak terbukti berpengaruh, hal ini disebabkan karena laporan keuangan untuk sederhana sudah cukup untuk kredit dibawah 1 milyar. Hasil diatas menunjukan laporan keuangan yang baik akan membantu UKM mendapatkan lebih banyak pinjaman dari bank. Hal ini seharusnya menjadi perhatian para UKM untuk lebih fokus dalam melakukan pencatatan dan pelaporan keuangan yang baik. Sebagian besar UKM yang menjadi reponden pada penelitian pelaporan keuangan penting bagi perusahaan, berikut hasil wawancara dengan pemilik usaha $\mathrm{x}$ : "Laporan keuangan merupakan bentuk dari pertanggungjawaban atas usaha dan segala transaksi yang dilakukan, selain itu melalui laporan keuangan dapat dilihat suatu entitas tersebut sehat/tidak, dan mencerminkan bagaimana perkembangan usaha tersebut selama masa berdiri", pemilik usaha z berbeda dengan hasil penelitian narsa yang menyatakan UKM Namun, peneitian ini menemukan sedikit UKM yang kualitas laporan keuangan bagus, pada tabel 4.2 terlihat hanya 13,26\% UKM yang memiliki kualitas laporan keuangan bagus, 31\% masuk kategori sedang dan 22,43\% buruk.

Informasi atau sosialisasi, latar belakang pendidikan memiliki pengaruh yang positif dan signifikan terhadap pemahaman pengusaha mengenai SAK ETAP. Pemahaman mengenai SAK ETAP masih cenderung rendah, hal ini juga sejalan dengan minimnya sosilaisasi yang diterima pengusaha UKM mengenai SAK ETAP dan pentingnya SAK ETAP. Kualitas laporan keuangan UKM masih sedikit yang berada dalam kategori bagus, salah satu kendala utamanya adalah kurang pahamnya mereka mengenai cara melakukan pembukuan yang baik. Sehingga perlu dilakukan sinergi antara Pemerintah, UKM, IAI dan perguruan tinggi untuk terus meningkatkan kualitas laporan keuangan UKM dan memberikan pelatihan yang intensif mengenai cara melakukan pembukuan dan implementasi standar akuntansi keuangan untuk UKM.

Kesimpulan, Implikasi dan Batasan Penelitian

Penelitian ini menemukan bahwa informasi atau sosialisasi, latar belakang pendidikan memiliki pengaruh yang positif dan signifikan terhadap pemahaman pengusaha mengenai SAK ETAP. Peneliti juga menemukan kualitas laporan keuangan menjadi salah satu pertimbangan pihak ekternal dalam pengambilan keputusan dalam hal ini adalah pemberian kredit. Namun, penerapan standar akuntansi oleh UMKM tidak terbukti berpengaruh. Keterbatasan penelitian ini adalah sampel yang masih kecil, peniliti kesulitan dalam mendapatkan sampel karena kebanyakan UMKM enggan memberikan informasi mengenai penghasilan, aset dan jumlah mereka. Sampel yang menerapkan SAK ETAP masih terbatas, hal ini karena beberapa perusahaan yang sudah menerapkan masih enggan untuk menjadi reponden. Penelitian berikutnya dapat menambahkan sampel dan perbandingan antara perusahaan yang menerapkan juga sebaiknya seimbang. Fokus pada perusahaan menengah yang memeiliki kredit diatas 1 Milyar

\section{Simpulan dan saran}

Penelitian ini menemukan bahwa informasi atau sosialisasi, latar belakang pendidikan memiliki pengaruh yang positif dan signifikan terhadap pemahaman pengusaha mengenai SAK ETAP. Peneliti juga menemukan kualitas laporan keuangan menjadi salah satu pertimbangan pihak ekternal dalam pengambilan keputusan dalam hal ini adalah pemberian kredit. Namun, penerapan standar akuntansi oleh UMKM tidak terbukti berpengaruh. Keterbatasan penelitian ini adalah sampel yang masih kecil, peniliti kesulitan dalam mendapatkan sampel karena kebanyakan UMKM enggan memberikan informasi mengenai penghasilan, aset dan jumlah mereka. Sampel yang menerapkan SAK ETAP masih terbatas, hal ini karena beberapa perusahaan yang sudah menerapkan masih enggan untuk menjadi reponden. Penelitian berikutnya dapat menambahkan sampel dan perbandingan antara perusahaan yang menerapkan juga sebaiknya seimbang. Fokus pada perusahaan menengah yang memeiliki kredit diatas 1 Milyar

\section{Daftar Rujukan}

Ajzen, I. (1991). The theory of planned behavior. Orgnizational Behavior and Human Decision Processes, 50, 179-211. https://doi.org/10.1016/0749-5978(91)90020-T

(2005). Attitudes, Personality and Behavior, (2nd edition), Berkshire, UK: Open University Press-McGraw Hill Education. 
Aidis, Ruta. 2005. "Institutional Barriers to Small- and Medium-Sized Enterprise Operations in Transition Countries." Small Business Economics 25(4):305-18.

Allee, K. D \& Teri, L.Y. 2009. "The Demand for Financial Statements in an Unregulated Environment: An Examination of the Production and Use of Financial Statements by Privately Held Small Businesses." Accounting Review 84(1):1-25.

Arismawati, K. N., Atmadja, A. T., \& Sulindawati. (2017). Pengaruh Tingkat Pendidikan, Pemahaman Akuntansi Koperasi Berbasis Sak-Etap, Kematangan Usia, Perilaku, Dan Efektivitas Kinerja Terhadap Kualitas Laporan Keuangan Koperasi Simpan Pinjam Di Kabupaten Buleleng. E-Journal S1 Ak Universitas Pendidikan Ganesha Jurusan Akuntansi Program S1, 8.

Arsyad, Lincolin. 2004. Ekonomi Pembangunan. Edisi Keempat. STIE YKPN.

Auliah, Iim Ma’Rifatul. 2012. "Penerapan Akuntansi Berdasarkan SAK ETAP pada UKM Kampung Batik di Sidoarjo." Surabaya: Sekolah Tinggi Ilmu Ekonomi PERBANAS.

Badan Pusat Statistik. 2006. Analisis Profil Perusahaan/Usaha Indonesia.

Bank Indonesia. 2011. "Pengembangan Komoditas/Produk/Jenis Usaha Unggulan UMKM di Provinsi Bali." Denpasar : Bank Indonesia dan Universitas Udayana.

Cassar, Gavin. 2009. "Financial Statement and Projection Preparation in Start-up Ventures.” Accounting Review 84(1):27-51.

Chanchani Shalin, Willett Roger. 2004. An empirical assessment of Gray's accounting value constructs. The International Journal of Accounting 39, 125- 154.

Chen, Feng, Ole Kristian Hope, Qingyuan Li, and Xin Wang. 2011. "Financial Reporting Quality and Investment Efficiency of Private Firms in Emerging Markets.” Accounting Review 86(4):1255-88.

Ghozali, Imam. 2013. Aplikasi Analisis Multivariate dengan Program SPSS. Semarang: Badan Penerbit Universitas Diponogoro

Fitakhurrokhmah. 2013. Pengaruh Persepsi Kemudahan Penggunaan dan Persepsi Kegunaan terhadap Penggunaan SAK ETAP pada Bank Perkreditan Rakyat di Malang Raya, (online), (jimfeb.ub.ac.id/index.php/jimfeb/article/download/251/200, diakses 13 September 2014).

Ikatan Akuntan Indonesia. 2009. Standar Keuangan Entitas Tanpa Akuntabilitas Publik

Lesceviva, M. 2004. Rural Entrepreneurship Success Determinant. Papers. Faculty of Economics, Latvian University of Agriculture, Eksjo, Latvian. Mackenzie, Bruce, dkk. 2012. Applying IFRS for SME.

Maupa, Haris. 2004. Faktor-Faktor yang Menentukan Pertumbuhan Usaha Kecil di Sulawesi Selatan. Disertasi Program Pascasarjana Unhas.

McCormick, D., M.N. Kinyanjui and G. Ongile. 1997. Growth and Barriers to Growth Among Nairobi,s Small and Medium Size Garment Producers. World Dev., Vol.25, No.7, pp.1095-1110.

Nurbasya, Yudhistira. 2011. Pelatihan ETAP - PSAK 45, Januari 2011. (http://www.keuanganlsm.com/2011/01/28/penabulu-pelatihan-etap-psak-45-januari-2011/), diakses 25 Juli 2014.

Ngadiman, Sohidin Arri Alfitri. 2014. “Penerapan Standar Akuntansi Keuangan Entitas Tanpa Akuntabilitas Publik (Sak-Etap) Pada Usaha Mikro Kecil Menengah (Umkm) Perajin Mebel Desa Gondangsari Kecamatan Juwiring Kabupaten Klaten." Jurusan Pendidikan Ekonomi Bidang Keahlian Khusus Akuntansi Universitas Sebelas Maret 2(2):135-47.

Prasetya, Ferry Danu. 2012. "Perkembangan Standar Akuntansi Keuangan di Indonesia”. Dalam : Jurnal Ilmiah Mahasiswa Akuntansi Volume 1. ; 204-214.

Ramadhan, Adhitya Wahyu., Syafrudin, Muchamad. 2012 Pengaruh Dimensi Nilai Budaya Terhadap Dimensi Nilai Akuntansi. eprint.undip.ac.id

Rudiantoro, R., Siregar, S.V. 2012. "Kualitas Laporan Keuangan UMKM serta Prospek Implentasi SAK ETAP". Dalam : Jurnal Akuntansi dan Keuangan Indonesia Volume 9- No 1. ; 1-21.

Rejekiningsih, Tri Wahyu. 2004. Mengukur Peranan Industri Kecil Dalam Perekonomian di Provinsi Jawa Tengah, Jurnal Dinamika Pembangunan, Volume 1, No.2 : hal 125-136. 
Olango, Eric Odhiambo. 2014. "The Effects of International Financial Reporting Standards Adoption on Smes Performance : A Case Study Mombasa - Central Business District ( CBD )." Research Journal of Finance and Accounting 5(7):94-103.

Prasetya, Ferry Danu. 2012. "Perkembangan Standar Akuntansi Keuangan di Indonesia". Dalam : Jurnal Ilmiah Mahasiswa Akuntansi Volume 1. ; 204-214.

Sari, Dita Purnama. 2012. "Analisis Faktor-Faktor yang Mempengaruhi Peyediaan dan Penggunaan Informasi Akuntansi pada UKM di Kecamatan Rumbai Pesisir." Pekanbaru: Universitas Riau.

Siskayani, Gusti Ayu Komang. 2013. "Pengaruh Pendapatan Provisi dan Komisi Kredit Sesudah Implementasi SAK ETAP Terhadap Laporan Keuangan PT. BPR Bali Dananiaga Denpasar". Dalam : Jurnal Akuntansi Universitas Udayana 3.3. ; 49-64.

Sugiyono, 2008. Metode Penelitian Kunatitatif Kualitatif dan R\&D. Bandung Alfabeta.

Zhang, Y. 2001. Learning Function and Small Business Growth, Management Accounting Journal, MCB University Press, Vol 15 No.26, pp. 228-231 